\title{
SALAHUDDIN WAHID AND THE DEFENCE OF MINORITY RIGHTS IN CONTEMPORARY INDONESIA
}

\author{
Asfa Widiyanto \\ State Institute for Islamic Studies (STAIN) Salatiga, Indonesia \\ email:asfa.widiyanto@gmail.com
}

\begin{abstract}
This paper discussed the role and authority of Salahuddin Wabid, a prominent muslim scholar, who actively promotes the minority rights in modern-day Indonesia. His credentials as a traditional ulama coming from the tradition of a pesantren allow him to become an authority in Islamic matters. Salabuddin's recognition as muslim scholar is in some ways observable from his responses to religious questions posed by the people, either directly or through social media. A general observation of Salabuddin's Twitter account will allows us to realize that he also represent an authority in "cyber-Islam". He felt the growing importance of social media, as well as the necessity to promote inclusive religiosity and the respect of minority rights through social media, accordingly he actively promotes his ideas through social media most particularly Twitter. Some issues have been discussed to overview Salahuddin's ideas to bestpromote minority rights. His activism can be felt most notably in the following issues: ethnic minorities, women's rights, religious minorities, diminishing the violence against the Ahmadiyya, and the marriage of religious minorities.
\end{abstract}

Paper ini membincangkan peran dan otoritas Salabuddin Wabid, seorang intelektual muslim terkemuka yang aktif mempromosikan bak-bak kelompok minoritas di Indonesia. Karisma yang dimilikiny a sebagai seorang ulama yang berasal dari kalangan pesantren tradisional memberinya sebuah otoritas dalam berbagai aspek ajaran Islam. Keulamaannya dalam batas tertentu dapat ditelusuri lewat respons yang diberikan atas pertanyaan masyarakat yang diajukan kepadanya, baik secara langsung maupun lewat 
sosial media. Pengamatan umum terbadap akun Twitter Salabuddin Wabid sekaligus menunjuk.kan otoritasnya di dunia maya. Dia sadar betulpentingnya sosial media sebagaimana pentingnya mempromosikan keberagamaan inklusif dan penghormatan terhadap bak-hak kelompok minoritas. Karenanya, dia aktif menyuarakan pendapatnya lewat sosial media, khususnya Twitter. Beberapa masalah didiskusikan dalam tulisan ini untuk. melihat secara umum pemikiran Salabuddin Wabid terkait dengan hak-hak kelompok minoritas: minoritas etnis, minoritas agama, hak-hak perempuan, kekerasan terhadap Ahmadiyyah, dan pernikahan antar agama.]

Keywords: minority rights, ethnic minority, religious minority, cyber Islam.

\section{A. Introduction}

Since ancient time, minorities have been in weak position and become the natural targets of genocide and persecution. In modern time, which is regarded a period of relative tolerance and rationality, we also witness that minorities at times become the targets of discrimination and repression. ${ }^{1}$ In the new-order Indonesia we encounter some government programmes which are aimed at civilizing and developing indigenous minorities throughout the country. ${ }^{2}$ We also come across many cases of discrimination towards Chinese minorities, especially during the New Order. In the present-day Indonesia, cases of discrimination and violence towards religious minorities are still prevalent.

We witness a number of Indonesian scholars who play a strong role in defending minority rights, one of them is Salahuddin Wahid. This present study is dealing with the role and authority of this scholar-activist in promoting the minority rights in modern-day Indonesia.

\section{B. The Discourse on Minority Rights}

Minority is conceived by Francesco Capotorti as "a group numerically inferior to the rest of the population of a state, in a nondominant position, whose members --being nationals of the state--

${ }^{1}$ Javaid Rehman, The Weaknesses in the International Protection of Minority Rights (Boston: Kluwer Law International, 2000), p. 3.

${ }^{2}$ Christopher R. Duncan, "From Development to Empowerment: Changing Indonesian Government Policies toward Indigenous Minorities", in Civilizing the Margins: Southeast Asian Government Policies for the Development of Minorities, ed. by Christopher R. Duncan (Ithaca: Cornell University Press, 2004), pp. 86-115. 
possess ethnic, religious or linguistic characteristics differing from those of the rest of the population and show, if only implicitly, a sense of solidarity, directed towards preserving their culture, traditions, religion or language". ${ }^{3}$ Kymlicka outlines three distinctive stages of the discourse on minority rights. ${ }^{4}$ The first phase of the debate is situated within the context of contestation between liberalism and communitarianism. Minority rights, in this sense, are perceived as a resistance of communallyminded minority groups against the intrusion of liberal individualism. In this regards, one may see that the defence of minority rights fall within the concern of communitarianism. The second phase of the discourse deals with possible scope for minority rights within the framework of liberal theory. The liberal theorists discord about the appropriate role that the nationality, language, and ethnic identities might play within the framework of democratic societies and institutions. Groups affirming minority rights (often labelled as "liberal culturalists") argue that some forms of recognition for the minorities' practices, languages, and identities are not only in conformity to liberal principles but also necessitated by them. ${ }^{5}$

Kymlicka classifies the rights (that a minority group may assert) into two clusters: (a) "internal restrictions" and (b) "external protections"). ${ }^{6}$ "Internal restrictions" are concerned with the rights that a particular group may exert against its own members, which aims at preventing the group from destabilisation. "External protections" deal with the rights that a group may exert against the broader society. The third stage of the debate turns around the question how some minority rights claims are a reaction to, or connected to, nation-building policies. There are at least three varied strategies which the minorities may take in terms of majority nation-building: (a) admitting the integration into the majority societal culture; (b) striving to establish their own societal culture and contesting to state nation-building; (c) accepting the enduring marginalisation. ${ }^{7}$

It is worth emphasizing that in the context of Indonesia, minority rights mainly refer to common rights of citizenship which are also

3 "Minorities Under International Law", United Nations Human Rights (2010), http://www.ohchr.org/EN/Issues/Minorities/Pages/internationallaw.aspx, accessed 21 Sep 2013.

${ }^{4}$ Will Kymlicka, Politics in the Vernacular: Nationalism, Multiculturalism, and Citizenship (Oxford: Oxford University Press, 2001).

${ }^{5}$ Ibid.

${ }^{6}$ Ibid.

${ }^{7}$ Ibid. 
accorded for minority rather than to special rights which are granted to the minority in recognising their practices and languages. Palguna rightly observe that in principle there are no particular constitutionally guaranteed rights that are bestowed to certain Indonesian people exclusively on the ground of their religion, ethnicity, social status or region. ${ }^{8}$

Palguna goes on to say that there is a certain portion of recognition to the specific rights in Indonesian Constitution. These specific rights are exclusively granted to the so-called "customary legal entities" (Kesatuan Masyarakat Hukum Adat) and to specialized regional institutions (like the province of Aceh, Jakarta, and Yogyakarta). ${ }^{9}$ It is worth mentioning that these customary legal entities refer to certain traditional communities within Indonesian societies, in which the provisions of customary law (bukum adat) become one source of law. The official explanation of the National Constitution however prescribes that these provisions of customary law are not to run contrary to the principles of the Unitary State of the Republic of Indonesia. The implementation of the provisions of customary law is further regulated by regional bylaws issued by the Regional People's Representative Council.

It seems to me that the "customary legal entities" share some features with, what Kymlicka labels as, "autochthonous minorities" but they do not necessarily represent the "autochthonous minorities". Kymlicka distinguishes between "autochthonous minorities" (new minorities) and "non-autochthonous minorities" (traditionally settled minorities) for his discussion of the basis of minority protection. In some countries, it is only autochthonous minorities which are eligible to minority protection, in the sense of possessing specific rights in developing their "societal culture". ${ }^{10}$

Pertaining to the discussion of religious minority, the notion of religion in the context of Indonesia is worth particular remarking. In 1952 the Ministry of Religion, which was dominated by muslims, brought out a restricted definition of religion: a religion should possess a holy book

${ }^{8}$ I. Dewa Gede Palguna, "Minority Rights in Indonesia: In Search of Suitable Legal Remedy for Constitutional Complaint", in State, Law and Religion in Pluralistic Societies Austrian and Indonesian Perspectives: Austrian-Indonesian Dialogue Symposium, ed. by Astrid Hafner, Sabine Kroissenbrunner, and Richard Potz (Vienna: Vandenhoeck \& Ruprecht, 2010), p. 131.

${ }^{9}$ Ibid.

${ }^{10}$ As cited by Julija Sardelić, “Constructing 'New' Minorities: An Evaluation of Approaches to Minority Protection in Post-Socialist Slovenia from the Perspective of Liberal Multiculturalism”, Journal for Ethnic Studies, no. 67 (2012), pp. 100-23. 
and a prophet. This sort of definition rules out the "mystical movement" and "local indigenous religion" as legitimate religious expressions of the Indonesian people. ${ }^{11}$

It is not easy to interpret the census of Indonesia which indicates that Muslims comprise $88 \%$ of the population, Christians $5 \%$, Hindus $2 \%$, Buddhists $0,8 \%$, and Confucianists $0,3 \%$. This is due to the plurality within and outside these religions. Many people embrace these "stately recognised religions" simply because they wish to secure the protection from the government. They are nominally recorded as the followers of these religions, but in practice, they still maintain to some extent the rituals of their respective local religions. ${ }^{12}$ When we look into that census, it is apparent that Muslims constitute the majority of the population, but it does not necessarily mean that the minority religions are marginalized. We can observe this in the case of Christians who exert a strong influence in the society, from colonial time until nowadays. ${ }^{13}$

\section{Short Biography of Salahuddin Wahid}

Salahuddin Wahid was the vice chairman of the national board of human rights (2002-2007). His standing as national figure can be observed for instance from the fact that he was named as one of the candidates of Indonesian vice-presidents in 2009. He is also recognised as one of outstanding scholars of the country as can be seen from the fact that the Kompas daily newsletter listed him as one of the "five dedicated scholars" of the country. ${ }^{14}$

Salahuddin has produced some books including Negeri Di Balik Kabut Sejarab: Catatan Catatan Pendek Salabuddin Wabid (The Country behind the Shadow of History: Short Essays of Salahuddin Wahid) (2000) and Mendengar Suara Rakyat: Catatan-catatan Pendek Salabudin Wabid (Listening to the People's Voices: Short Essays of Salahuddin Wahid) (2001). Salahuddin is concerned with a certain spectrum of religious

11 Niels Mulder, Mysticism and Everyday Life in Contemporary Java: Cultural Persistence and Change (Singapore: Singapore University Press, 1978), p. 22.

${ }^{12}$ Marburg Franke and Katrin Gotterbarm, "Kritik durch Anpassung? Aluk to dolo und Christentum im Pancasila-Staat Indonesien", in Religionsinterne Kritik und religiöser Pluralismus im gegenwärtigen Südostasien, ed. by Manfred Hutter (Frankfurt: Peter Lang, 2008), pp. 217-28.

${ }^{13}$ Ibid., p. 217.

${ }^{14}$ Ana Shofiana Syatiri, "Kompas Anugerahi Lima Cendekiawan Berdedikasi 2013”, Kompas.com (27 Jun 2013), http:/ / sains.kompas.com/read/2013/06/27/1144192/ Kompas.Anugerahi.Lima, accessed 3 Sep 2013. 
pluralism, namely emphasizing tolerance and respect of minority rights. Salahuddin's commitment to eradicate intolerance can be perceived from his defence to the head of Lenteng Agung village in Jakarta. The newly elected head of the village was demonstrated by some of her constituents who disagreed with the election due to the fact that her religious convictiowwin differs to that of her constituents. ${ }^{15}$ Salahuddin plays a role in minimizing intolerance within the Nahdlatul Ulama (Indonesia's largest Islamic organization), as can be observed from his recommendation to the kiais (Muslim scholars) of Madura to reconcile without any prerequisite with the Shi'ite adherents at the region. ${ }^{16}$

Besides, Salahuddin is concerned with the conflict-reconciliation, as can be observed from his involvement in reconciling the conflict between Muslims and Christians which broke out in 1999 in Ambon. His concern with conflict-reconciliation can be also perceived from his involvement in lessening the conflict between the supporters of Abdurrahman Wahid (which comprise mainly from the members of the Nahdlatul Ulama) and the supporters of Amien Rais (which comprise mostly from the members of the Muhammadiyah, Indonesia's second largest Islamic organization) regarding the special session of the People's consultative assembly, which was held in July 2001, which targeted the impeachment of Abdurrahman Wahid from presidency. ${ }^{17}$

Salahuddin's standing in the field of education can be discerned from the title of Doctor Honoris Causa which he obtained on 10 December 2011 from State Islamic University (UIN) Maulana Malik Ibrahim, Malang, Indonesia. He was granted this award due to his academic achievement and his dedication to manage the activities of Islamic education, most notably in confirming and continuing the development in the Pesantren Tebuireng, Jombang, East Java. ${ }^{18}$ In his scientific oration entitled "Transformasi Pesantren Tebuireng: Menjaga

${ }^{15}$ Rina Atmasari, "Soal Lurah Susan, Ini Kata Gus Sholah", Tempo.co (13 Jul 2013), http://www.tempo.co/read/news/2013/08/23/083506850/Soal-Lurah-SusanIni-Kata-Gus-Sholah, accessed 9 Sep 2013.

${ }^{16}$ Arief Rizqi Hidayat, "Salahuddin Wahid Sesalkan Sikap Ulama Madura", Tempo.co (24 Jul 2013), http://www.tempo.co/read/news/2013/07/24/078499266/ Salahuddin-Wahid-Sesalkan-Sikap-Ulama-Madura, accessed 17 Sep 2013.

${ }^{17}$ Salahuddin Wahid, Berguru pada Realitas, Refleksi Pemikiran Menuju Indonesia Bermartabat (Malang: UIN-Maliki Press, 2011), pp. 119-55.

18 "Doctor HC Pertama di UIN Maliki", The Center of Excellence and Islamic Civilization (9 Oct 2011), http://uinsite.uin-malang.ac.id/blog/2011/12/doctor-hcpertama-di-uin-maliki, accessed 17 Sep 2013. 
Tradisi di Tengah Tantangan" (The Transformation of Pesantren Tebuireng: Maintaining Tradition amidst Challenges), Salahuddin revealed the unique features of pesantren as an educational institution. He points out that the pesantren is people's sponsored educational institution which has enlightened the people in the Indonesian archipelago before the intrusion of Dutch system of education. Pesantren has contributed to the moulding of Islamic spirit which is able to dialogue smoothly with the local culture as well as the dynamics of civilization. ${ }^{19}$

His leadership at the Pesantren Tebuireng (2006-present) constitutes his new role, which is to some extent does not match his formal educational background; his elementary and intermediate formal education were not gained in Islamic schools. His bachelor degree was obtained from Bandung Institute of Technology. He even once served as the associate director in one international property firm, from 1995-1996. It is perhaps due to this formal educational background, Salahuddin admits that he is not a Muslim scholar who is able to teach Islamic knowledge, on the one hand. ${ }^{20}$ On the other hand, he realizes his wide reception among the pesantren stakeholders due to the fact that he was a descendant of Hasyim Asy'ari and his own potentials, most particularly the capacity in communicating with different parties, which is of significance in developing the pesantren.

Salahuddin labels himself as the "engineer which strives to develop the pesantren". ${ }^{21}$ His appointment as the leader of the pesantren is accordingly considered breaking the mainstream. The former leader of the Pesantren Tebuireng, Yusuf Hasyim (1929-2007), expressed his consideration in the following words:

Considering the fact the Pesantren Tebuireng is an institution which has national reputation, its leader should be someone who has good reputation at the national level as well. There are two candidates who may replace my position: Abdurrahman Wahid and Salahuddin Wahid. From the side of knowledge, Abdurrahman is obviously better; but from the side of health and availability, Salahuddin is better. Herewith I decide Salahuddin to be the next leader of the Pesantren Tebuireng. ${ }^{22}$

At this point, we may observe Salahuddin's varied roles ranging

${ }^{19}$ Ibid.

${ }^{20}$ Salahuddin Wahid, Transformasi Pesantren Tebuireng: Menjaga Tradisi di Tengah Tantangan (Malang: UIN Maliki Press, 2011), pp. 127-28.

${ }^{21}$ Wahid, Berguru pada Realitas, pp. 139-44.

${ }^{22}$ Wahid, Transformasi Pesantren Tebuireng, pp. 125-6. 
from engineer, politician, human rights activists, the leader of a pesantren, to a muslim scholar. Salahuddin's recognition as a muslim scholar is to some extent detected from his responses in Twitter pertaining to the religious questions posed by the people.

Roles are presumed by interactionism to be unceasingly remade in connection with relevant others; and this imposes the identification of the grounds on which roles are differentiated. Differentiation in this sense refers to two aspects: (a) sorting and secerning diverse actions and sentiments, and incorporating them into distinct roles; (b) accumulating and adding behaviors to specific roles. ${ }^{23}$ We may analyze Salahuddin's role in the light of this theoretical framework. We may view Salahuddin's role differentiation in two ways: (a) there have been processes of sorting diverse actions and sentiments; in accordance with subjects' and holder's aspirations, demands and desires; and incorporating them into Salahuddin's "new distinct role"; (b) there have been processes of adding behaviors and tasks to Salahuddin's specific role. It is assumed, that Salahuddin's previous specific role is one of these roles: "Muslim scholar", "human rights activist", "politician" or "engineer".

\section{Salahuddin Wahid and His Authority Credentials}

Salahuddin Wahid learned in the pesantren of his father, the Pesantren Tebu Ireng. The training in this traditionally acknowledged institution renders him qualification as a muslim scholar. Despite the fact that Salahuddin obtained his bachelors' degree from secular university, he has been recognized as a muslim scholar, and consequently appointed as the leader of the Pesantren Tebu Ireng.

Salahuddin is noticeable from the greater part of his audience by the fact that he is thoroughly proficient in classical Arabic. This proficiency facilitates him in understanding the major texts of Islam, including the Quran, hadith, Islamic law, and Islamic mysticism. The proficiency in classical Arabic and subsequent mastering of classical Islamic texts thus constitute important credentials of Salahuddin's authority. In his sermons, Salahuddin often quotes Quranic verses and Prophetic sayings. Such quotations are of significant to provide legitimacy of his discourses.

Salahuddin possesses an authority as faqih, a traditionally trained

${ }^{23}$ Ralph H. Turner, "Role Theory", in Handbook of Sociological Theory, ed. by Jonathan H. Turner (New York: University of California, 2006), p. 236. 
muslim legal scholar. His legal reasoning is acknowledged by many Indonesian scholars. A kiai or muslim scholar must at least master the rulings of figh, and he will be consulted by people pertaining to fiqh problems in the society. Salahuddin's standing as faqih can be observed for instance from people's consultation to him pertaining to matters of Islamic law, either directly or via social media.

Humphreys belongs to scholars that are convinced that Islamic law constitutes a significant part of muslim society. ${ }^{24}$ Further, he argues that Islamic law is a significant source for social and economic life. Digests of positive law suggest that figh and sharia were not only rooted in social ideals but also in social reality. Among the Malikite, adaptation to the social realities took the form of 'amal, a concept which allowed a qàdì or mufti to regard established local custom and necessity in framing his rulings. As the positive content of sharia was increasingly defined by authoritative compilations, commentaries, and digests, the fatwa became the most important tool for addressing contested issues. From the 6th/12th century, it became common for eminent faqibs or their disciples to collect and publish their fatwas. The extant legal documents can be divided into three broad classes, Sharia-court records, deeds of waqf, and contracts on subjects of all kinds.

Salahuddin's success is to some extent to the rareness of traditionally trained religious authorities who are familiar with contemporary issues and modern social media. Salahuddin is able to communicate contemporary issues by using simple language so that it can reach the majority of the muslim community in Indonesia. The community's recognition to the authority of religious leader is observable from the support they provide to him; such as providing him leave of absence from taking part in communal labour obligations and supporting his travel expenditures. ${ }^{25}$ The similar can be said about kiai in Indonesia, including Salahuddin. They enjoy support from the community. The community usually give him leave of absence from communal labour responsibility even they will voluntarily do some works

${ }^{24}$ R. Stephen Humphreys, Islamic History: A Framework for Inquiry (New York: Princeton University Press, 1991).

${ }^{25}$ G. Lyons, "From Advanced Towards Effective Traveller Information Systems", in Travel Behaviour Research: The Leading Edge, ed. by David A. Hensher (Pergamon Press, 2001), pp. 813-26, http:/ / eprints.uwe.ac.uk/8550/1/8550.pdf, accessed 1 Jun 2014. 
for him, such as erecting and maintaining his pesantren. They also provide financial support to the kiai and his pesantren. The kiai usually belongs to those responsible for receiving and distributing the zaka (almsgiving), accordingly he serves as one of economic axis in muslim community.

Salahuddin's credential of authority is one thing, and the people's acknowledgement of Salahuddin's authority serves to accentuate his possession of authority. The recognition of Salahuddin's authority can be also detected from the number of people who are attracted to attend Salahuddin's religious gatherings (pengajian), and from the personages who regularly invite Salahuddin to deliver a talk to their forums. In Youtube we witness many videos of Salahuddin's preaching, which were attended by many people.

Salahuddin is regarded as an authority among Muslims in Indonesia, in the sense that he acts as a mufti (jurist consult), whom people ask guidance regarding their religious problems. People's eagerness to consult Salahuddin on religious matters can be perceived as their recognition of Salahuddin's authority. People's recognition of Salahuddin's authority can also be seen from people's appreciation to Salahuddin's opinions in Youtube. This can be observed for instance in Youtube video entitled "Tanggapan Gus Solah atas Sosok Jokowi" (Salahuddin's response to the figure of Joko Widodo). ${ }^{26}$ This video was viewed 32.193 times, attracted 276 likes, 6 dislikes, and 25 commentaries. This video was uploaded two months before Indonesian presidential election on 9 July 2014. Many people were interesting in watching this video since they are curious to know Salahuddin's political preference and vision regarding presidential election. It is worth remarking that Salahuddin is considered an influential figure in the circle of Nahdlatul Ulama, accordingly his political preference most likely become the reference among this circle.

Salahuddin's authority is in some ways inherited from his father Wahid Hasyim (1914-1953) a well-known religious scholar who led the Pesantren Tebu Ireng, Jombang, East Java. Wahid Hasyim served as the first minister of religion under Soekarno's regime. He held this position in 1945, and from 1949 to 1959 Salahuddin is believed to inherit some of his father's charisma. ${ }^{27}$ The son of a kiai in Indonesia is normally called

26 “Tanggapan Gus Sholah Terhadap Sosok Jokowi", Youtobe.com (4 May 2014), https:/ / www.youtube.com/watch?v=ugSXgLCx_ys\&feature=youtube_gdata_player, accessed 17 Sep 2014.

${ }^{27}$ Charisma is at times defined as a certain quality by which a person is treated as if they have superhuman or at least extra-ordinary qualities; Parrinder Geoffrey, 280 Al-Jāmi'ah, Vol. 52, No. 2, 2014 M/1435 H 
"Gus" (literally means "handsome"), so "Gus" is the noble title for the santri community. A well-known saying circulated in the santri community reads "the son of lion should become a lion, not a cat". This indicates that the leader's charisma can be effectively and fully transferred to his son. ${ }^{28}$ Accordingly many kiais are anxious if they do not have sons whom they could transfer their charisma and whom they trust in continuing their leadership. A son is deemed to be the best sort of successor for his father. Cases in which the son of a kiai is not willing, for instance, to take over to the position of his father are regarded as a sign of the fading charisma of the family, all the more so if there is no one to succeed the kiai.

In Max Weber's view, total trust in the leader is among the signs of charisma. ${ }^{29}$ What is apparent in the charisma is that this, from sociological point of view, is in some ways marked by recognition from a group of people. In Javanese society in general, one possessing charisma is believed to have better chances of filling an important position in society. Such a person normally possesses a strong "inner-feeling" (rasa) resulting from practicing mystical disciplines. The idea of "inner-feeling" itself, as one publication indicates, ${ }^{30}$ underlies the possibility of personal experience and feeling as the ultimate touchstones for the truth. This mode of thought is based on the acknowledgment that there is always something implicit and non-rational within most phenomena and experiences.

We can see that the phenomenon of employing mystical practices for the sake of yielding potency and efficacy is not uncommon in Javanese society. The existence of charisma as a legitimacy for leadership is present in most societies. However, the source of this charisma may differ from one society to another. Salahuddin's credentials of authority are in some ways distinct to those of Muslim televangelists, in the sense that these televangelists mostly did not undertake a classical training in Islamic

"Peace", in The Encyclopedia of Religion, ed. by Mircea Eliade and Charles J. Adams (New York: Macmillan, 1987). One publication indicates that charisma is much more a quality attributed to a person by the people, particularly his followers, rather than his real quality. In other words, the attribution of charisma is mostly grounded on the conviction of the people, rather than that the person concerned possesses power or any other extraordinary quality; Richard C. Anderson, "How to Construct Achievement Tests to Assess Comprehension”, Review of Educational Research, vol. 42, no. 2 (1972), pp. 145-70.

${ }^{28}$ The transfer of charisma is designated, in the vocabulary of Max Weber, as "routinisation"; Reinhard Bendix, "Reflections on Charismatic Leadership", Asian Survey, vol. 7, no. 6 (1967), pp. 341-52.

${ }^{29}$ Ibid.

${ }^{30}$ Mulder, Mysticism and Everyday Life in Contemporary Java. 
scholarship (either from the Pesantren or from any respectable Islamic education institutions in the Middle East). Their authority rests mostly in their ability to relate Islamic doctrines with contemporary issues.

The closeness of identity between the televangelists and their audience also plays an important role in establishing the authority of these televangelists. Many of these televangelists identify themselves as ordinary human beings who are susceptible to commit sings, and accordingly address their audience in simple and humanist way. Some of these televangelists clearly admitted that they committed some big sins in the past, but after that the repent and asked God's forgiveness. The media, most notably the television, plays likewise an undeniable role in moulding the authority of these televangelists.

One may say that their authority is more susceptible to break down, if we compare this with that of the kiais, especially due to their unsound basis of authority. The relation between these televangelists and their audience takes in the form of "celebrity-fans" rather than "religious leader-followers". One may observe for instance the breakdown of this credibility in the case of Abdullah Gymnastiar. Gymnastiar lost most of his credibility as he conducted polygamy. It is worth remarking that many of his followers are females and they were attracted to listen Gymnastiar's preaching mostly due to the fact that he showed his great care to his wife in public which clearly indicated that he was a caring and ideal husband.

In this regards, Friedman's, lassification of "being an authority" is worth mentioning. Friedman categorizes "being an authority" into two sub-clusters: (a) "authority over beliefs", (b) "authority over conduct". 31 For Friedman, religious scholars, experts and parents are instances of those possessing "authority over beliefs"; whilst judges, generals and legislators possess “authority over conduct”. When we employ Friedman's categorization it becomes clear that the authority of such a religious scholar as Salahuddin falls into the sub-cluster "authority over beliefs".

Pertaining to the discourse on kiai, whether it represents a cultural broker, as advocated by Clifford Geertz, or a genuine entrepreneur of social change, as proposed by by Hiroko Horikoshi, I would rather stick to the latter standpoint. For Hirokoshi, as cited by Abdurrahman Wahid, ${ }^{32}$ the kiai plays an active role in selecting positive values and behaviors which

${ }^{31}$ Renee F. Friedman and Douglas J. Brewer, Fish and Fishing in Ancient Egypt (Cairo: American University in Cairo Press, 1990), p. 57.

${ }^{32}$ Pradjarta Dirdjosanjoto, Memelihara Umat: Kiai Pesantren, Kiai Langgar di Jawa (Yogyakarta: LKiS, 1999), p. xv. 
are to be developed in society, and accordingly sketches his own priority scales and initiatives in response to social change. It seems to me that this role is particularly relevant in cyber era nowadays. Despite the fact of overwhelming sources of information available on the internet, the kiai remains an authority pertaining to matters Islamic, most specifically the kiais who energetically employ Web 2.0 in disseminating their ideas. The kiai represent as moral and spiritual authority which inspire the people in social change.

The kiai, according to Horikoshi, is able to explain the complex theological problems to the farmers or laymen in accordance with their respective logic and or conscience. ${ }^{33}$ As a charismatic figure, a kiai is usually independent in making decision, and in his interaction with other elements of the society.

\section{Salabuddin Wabid, Religious Autbority and Social Media}

Salahuddin's standing as an authoritative figure can be also investigated with the help of social media, most notably Twitter and Facebook. In this regard, I will pay considerable attention to Salahuddin's presence in Twitter due to the fact that Twitter represents public oriented social media. Salahuddin's presence in Facebook can be perceived from the "fan page" dedicated to him. The fan page entitled "Salahuddin Wahid" succeeded in attracting 476 people to click the "like" bottom, as of November 4, 2014. Salahuddin's presence in Twitter is much more pervasive, since he possesses a Twitter account entitled @Gus_Sholah. This Twitter account attracted more than 259.000 followers, as of November 4, 2014. Salahuddin's activeness in Twitter can be seen from the number of his tweets which reach 32.000 as of November 4, 2014.

Twitter refers to "a popular micro-blogging and social network service that allows people to share messages" not exceeding 140 characters in length. ${ }^{34}$ Twitter represents an aspect of virtual reality. Some people are convinced that this realm of reality does not necessarily correspond to factual reality in the society. It must be admitted, however that the discourses in Twitter in some ways influence the policy and

${ }^{33}$ Hiroko Horikoshi, Kyai dan Perubahan Sosial: Kyai and Social Change, trans. by Umar Basalim and Andi Muarly Sunrawa (Jakarta: Perhimpunan Pengembangan Pesantren dan Masyarakat, 1987), p. 1.

${ }^{34}$ Lee M. Humphreys, Balachander Krishnamurthy, and Phillipa Gill, "How Much Is Too Much? Privacy Issues on Twitter", Paper presented at the annual meeting of the International Communication Association (Suntec City, Singapore, 21 Jun 2010), http:/ / www2.research.att.com/ bala/papers/ica10.pdf, accessed 28 May 2014. 
events in the society.

Twitter can be perceived as both form of communication and social organization. When we look into traditional Islamic scholarship, we begin to realise that the notion of "followers" in Twitter is comparable to the term mustami'un (listeners, audience). When we turn specifically to the followers of Salahuddin's Twitter account, we can also ascertain that some of these mustami'ün may fall into the category of muqalliduin (followers, adherents to Salahuddin's major ideas). Mustami'ün is a general term designated to those subscribed to read Salahuddin's ideas. Muqallidun is more specific in the sense that these persons do not only read Salahuddin's ideas, but also regard him as an authority, and accordingly consult him pertaining to some religious problems. Some of these "muqallidun" are treated by Salahuddin as "elite followers" (khawwàs) whom he follows and whose Tweets are sometimes retweeted. If we draw an analogy with traditional Islamic scholarship, "retweeting" is comparable to iqrär (confirming, approving). This group of muqallidun sometimes consults Salahuddin pertaining to religious problems.

The second variant of Salahuddin's mustami'ün is the so-called "fellows". This group of people serve as people with whom Salahuddin interact in more egalitarian mode. They are followed by Salahuddin. They do not consult Salahuddin, but rather discuss with him pertaining to some issues. The third variant of Salahuddin's mustami 'un is the so-called "critics". This group of people subscribes to view Salahuddin's ideas, but do not agree with him in some issues, and criticize him accordingly.

The quantity of "followers" weight on Twitter, at least due to two factors: (a) the high number of followers enhances the possibility of the spreading the messages; (b) users with high number of followers are considered more prestigious than those have limited number of followers. These two benefits make some people eager to increase the number of their followers, by interacting with people, following other users, and posting a fascinating information. Some people pursue another strategy in gaining more followers, they strive to manipulate the number of followers, by creating different Twitter accounts or by employing third party application that enable the users to obtain many followers. It seems that Twitter contributes to the establishing of narcissistic culture.

It is difficult to quantify the followers of a cleric, a saint or a prophet in pre-modern times. The situation is currently changing; with the emergence of Twitter the number of followers of the figures who register as 'Twitter users is quantifiable. When we look into Salahuddin's 284 Al-Jämíah, Vol. 52, No. 2, 2014 M/1435 H 
Twitter account, we begin to realize that he also represents as an authority in "cyber-Islam". He felt the growing importance of social media, as well as the necessity to promote inclusive religiosity and the respect of minority rights through social media; accordingly he actively promotes his ideas through social media most particularly Twitter. Salahuddin enthusiastically posts his tweets pertaining to religion, politics, law and other issues. It is worth remarking that almost every day he post his tweets. He has been consulted on many issues on matters Islamic covering: fiqh, morality, Sufism and theology. On figh related matters, Salahuddin has been consulted pertaining to such problems as ethics of replying greetings, prayer (most particularly the prayers of hajat, tahaijud, istikhara).

People's consultation to Salahuddin pertaining to fiqh is worth remarking. One Twitter user asked a question whether the optional dawn prayer (salat sunnat al-fajr) should be performed after or before adhan. In response to that, Salahuddin said, "I myself perform it after adhan". ${ }^{35}$ Another Twitter user posed a question regarding Quranic stipulation on tattoo. Salahuddin replies the question by saying diplomatically, "in my own opinion, tattoo is forbidden". ${ }^{36}$ It seems to me that Salahuddin's response is due to his awareness of the criticism of some conservative Muslims towards one Indonesian minister who has tattoo in her bodies. Salahuddin strives to avoid judging this minister since he is conscious that not all prescriptions of Islamic law are implemented in Indonesia, since Indonesia is not an Islamic state. Accordingly, when one Twitter user asked, "What about the minister's tattoo?" Salahuddin replied by saying, "that is her personal business". ${ }^{37}$ Modern figh issues such as blood donation are also consulted to Salahuddin. One Twitter user posed a question regarding Islamic law's standpoint on blood donation. Salahuddin responded to the question, by saying that, "If the donor is

${ }^{35}$ Salahuddin Wahid, “Saya sholat setelah Adzan@Randy_Hendra: @ Gus_Sholah Sholat sunnat fajar itu sebelum adzan subuh atau antara adzan-Iqmah dan beda dengan sunnat Qobliyah?", Twitter.com (00 - 29 Okt 2014), https:/ / twitter.com/ Gus_Sholah/statuses/527354232001671168, accessed 6 Nov 2014.

${ }^{36}$ Salahuddin Wahid, “Menurut saya tidak boleh.@sspamungkas: @Gus_ Sholah@pramono_ar@kurdiabujundi@bobihendra hukum tato Gus? menurut syariat Islam.”, Twitter.com (28 - 29 Okt 2014), https://twitter.com/Gus_Sholah/ statuses/527300973262163968, accessed 14 Dec 2014.

${ }^{37}$ Salahuddin Wahid, "Jangan merokok di tempat umum. @bobihendra: Kiay@Gus_Sholah,Bagaimana pendapat Kyai mengenai Mentri yang merokok dan bertato?”, Twitter.com (32 - 29 Okt 2014), https://twitter.com/Gus_Sholah/ statuses/527256640127389696, accessed 4 Nov 2014. 
healthy, he will reap rewards from God". 38

Salahuddin has done his best to enlighten the people the relative binding of a fatwa. This can discerned for instance from Salahuddin's reply to one Twitter user, who said, "The Majelis Ulama Indonesia issued a fatwa on the prohibition [of smoking], did not it?" In response to that, Salahuddin stressed that the fatwa is not binding. ${ }^{39}$ This Twitter user continued his question by saying, "Is the fatwa on halal and haram not applied to all people?" Salahuddin replied the question by stressing that such a fatwa is only applied to those who believe it. ${ }^{40}$

Salahuddin is also concerned with some people who strive to enforce all prescriptions of Islamic law in Indonesia without realizing that Indonesia is not an Islamic state. This can observed for instance in Salahuddin's reply to the question posed by one Twitter user. This Twitter user raised a question, "rajm (stoning) and qisas (equal retaliation) are not found in the national constitution, but are available in the Quran. So rajm and qisas are not applied in our country? Great! The national constitution defeats the Quran". In response to that, Salahuddin asserts that both rajm and qisas are not implemented in Indonesia. ${ }^{41}$ Salahuddin's enlightenment is also observed in his reply to the remark of another Twitter user, namely, "The chairman of Anshor (Youth branch of the Nahdlatul Ulama) said, 'national constitution is higher than religious law'. In response to that, Salahuddin stresses that religious law is implemented in Indonesia if it has been incorporated in the national constitution. ${ }^{42}$

${ }^{38}$ Salahuddin Wahid, "Kalo sehat, berpahala. @ode_ahmad: menurut pandangan ISLAM \#DonorDarah itu Halal pa Haram pak@Gus_Sholah?”, Twitter.com (26 - 30 Okt 2014), https://twitter.com/Gus_Sholah/statuses/527768395953864704, accessed 22 Dec 2014.

${ }^{39}$ Salahuddin Wahid, "Fatwa itu tidak mengikat. @navikindi: Bukankah MUI sudah menfatwakan kharam Gus?@Gus_Sholah@bobihendra”, Twitter.com (59 - 29 Okt 2014), https://twitter.com/Gus_Sholah/statuses/527263324442877952, accessed 2 Aug 2014.

${ }^{40}$ Salahuddin Wahid, "Berlaku hanya bagi yang percaya. @Condare: Apa fatwa tentang halal haram itu tidak berlaku atas semua orang? Aneh@navikindi @bobihendra", Twitter.com (06 - 29 Okt 2014), https://twitter.com/Gus_Sholah/ statuses/527295365783891969, accessed 2 Jun 2014.

${ }^{41}$ Salahuddin Wahid, “Tidak berlaku di RI.@aim_revolt:@fimadani Rajam dan Qishash gak ada di UU tapi ada di Qur'an. Gak berlaku berarti? Hebat. UU ngalahin Al-Qur'an", Twitter.com (30 - 15 Okt 2014), https:/ / twitter.com/Gus_Sholah/ statuses/522227956358205440, accessed 2 Dec 2014.

${ }^{42}$ Salahuddin Wahid, "Hukum Agama berlaku bila Ada di dlm UU. @ you_bram: Pripun niki? -@fimadani: Ketua GP Ansor: Di Atas Hukum Agama Ada Konstitusi Negara", Twitter.com (27 - 15 Okt 2014), https://twitter.com/Gus_Sholah/ 
Salahuddin has done his best to underline the necessity of enlightening the people pertaining to tolerance and respect towards nonMuslim minorities. This can be seen for instance from the question posed by one Twitter user, namely, "Does Islam teach us to hate other religions?" Salahuddin replies the question by asserting that Islam does not teach so. Questions on khilafah also appear on Salahuddin's timelines. One of these questions read as, "some Indonesian people are aspiring towards khilafah. What is your opinion of the necessity of khilafah?" Salahuddin answered the query by saying, "for me, it is not necessary". ${ }^{43}$ Another question reads as, "What is your opinion on khilafah?" Salahuddin replied, "Indonesian constitution does not recognise such system". ${ }^{44}$

When we read Salahuddin's postings in his timelines, we begin to realize an aspect of his agency. It seems to me that Salahuddin is aware of varied trajectories of action pertaining to the necessity of enacting Islamic state: (a) the support of Islamic state as, for them, Islam is concerned with both religion and state (al-islam din wa dawla); (b) the support of enforcing a big portion of Islamic law provisions in the country and the strive to establish Islamic society; (c) the support of plural Indonesian state by incorporating a limited portion of Islamic law in the national legal rulings; (d) the support plural and secular Indonesia without necessarily incorporating provisions of Islamic law in the national legal rulings, since they pay more attention to the spirit of Islam in contributing to the betterment of society rather than formalizing it in the legal regulations in the country. It seems to me that Salahuddin sticks to the third trajectory.

The supporters enactment of Islamic law in Indonesia are most notably Indonesian Party of Islamic Liberation (HTI), The Mujahidin Council of Indonesia (MMI), and Defenders Islamic Front (FPI). ${ }^{45}$ For Wahid, the MMI's strategies in enacting Islamic law are worth remarking since they has taken some tangible actions regarding the enforcement

statuses/522212087397769216, accessed 2 Dec 2014.

43 Salahuddin Wahid, “Menurut Saya tidak perlu.@pepesiwak: Yai@ Gus_Sholah beberapa umat Islam di Indonesia menginginkan berdirinya Khilafah, masihkah perlu yai?’”, Twitter.com (9 Nov 2014), https://twitter.com/Gus_Sholah/ statuses/528369309114830850, accessed 9 Jun 2014.

${ }^{44}$ Salahuddin Wahid, "Hukum RI, Tidak mengenal itu. @lutfisarif: Assalamu’alaikum@Gus_Sholah, bagaimana menurut njenengan hukum Al Khilafah atau Al Imamah Al 'Ushma?', Twitter.com (13 - 30 Okt 2014), https://twitter.com/ Gus_Sholah/statuses/527750022335442944, accessed 2 Dec 2014.

${ }^{45}$ Salahuddin Wahid, "Belajar dari Pemimpin Masa Lalu", SuperKoran.info (12 Mar 2007), pp. 80-1, http://superkoran.info/?p=1465, accessed 3 Dec 2007. 
of Islamic law most particularly by giving suggestion to amend some chapters of the national constitution so as to conform with Islamic law. Such tangible actions are not undertaken by other organizations including the FPI.

Salahuddin highlights the differing strategies in struggling for the implementation of Islamic law. From 1945 to 1959, The Nahdlatul Ulama once struggled for making Islam as the foundation of the state. In the following period, the Nahdlatul Ulama strived to include the "Jakarta charter" in the national constitution. Nowadays, the Nahdlatul Ulama attempts to incorporate "particular" provisions of Islamic law in the corpus of national legal system, most particularly via the production of Acts. This is distinct to PBB and MMI who struggle for enforcing Islamic law via the State Constitution. Another difference lies in the fact that the MMI and PBB struggle for the implementation of Islamic law as a whole, whilst the Nahdlatul Ulama does not include the ritual aspects of Islam ('ibäda maḥda) as the focus of its struggle. ${ }^{46}$ Salahuddin bases his argument that the Nahdlatul Ulama also struggle for the implementation of Islamic law on statute of this organization. He specifically refers to the chapter five of this statute which reads, "the goal of the Nahdlatul Ulama is to implement the teachings of Islam, according to the Ahl al-Sunna wa al-Jama'a, in the society in the Republic of Indonesia". Salahuddin interpret the phrase "teachings of Islam" as covering Islamic law. ${ }^{47}$

Ali rightly observes that the collapse of President Soeharto in 1998 brought an implication of more intensive contestation between moderate and conservative Islamic groups. ${ }^{48}$ This contestation is to be understood as religious-political contestation rather than mere religious contestation. Both groups strive to exert an influence on the silent majority part of Indonesian Muslim community.

The fall of Soeharto has also an implication to the changing role of the Majelis Ulama Indonesia (Indonesian Council of Muslim Scholars). During the national congress which was held in 2000, the MUI declared the change of its role, from being "the servant of the government" to "the servant of the Muslim community". This role shifting also has an

${ }^{46}$ Salahuddin Wahid, "Realitas 'NU' tidak Sesederhana yang Kita Bayangkan”, in NU Politik: Analisis Wacana Media, ed. by Fathurin Zen (Yogyakarta: LKiS, 2003), p. xiv.

${ }^{47}$ Ibid.

${ }^{48}$ Muhamad Ali, "Moderate Islam Movement in Contemporary Indonesia”, in Islamic Thought and Movements in Contemporary Indonesia, ed. by Rizal Sukma and Clara Joewono (Jakarta: Centre for Strategic and International Studies, 2007), p. 202. 
impact on MUI's products such as fatwas and tausiyyas which seem to be in conformity with conservative aspirations. ${ }^{49}$

\section{Salabuddin Wabid and Ethnic Minorities}

Salahuddin also shows his concern with the violence against ethnic minorities in Indonesia. This can be perceived from his attention and solution to the case of violence against Chinese minority which occurred in May 1998 preceding the fall of the President Suharto (reign 19661998). He predicts that the Chinese minority will be victims against if the country is in chaos. This is due to the envy of "poor majority" towards Chinese minority (which constitutes the "market-dominant minority")..$^{50}$

In the eyes of Salahuddin, in order to solve that problem the government should issue economic policies which take side which the people, most notably in urban areas whose residents are potential to involve in the chaos. The approach of many city mayors in dealing with traditional traders by displacing them for the sake of pleasing big capital owners (which mostly Chinese) is like putting a big amount of fireable materials. Salahuddin goes on to give an example in which city mayor has been able to take side with people. Joko Widodo (the former mayor of Surakarta, Central Java) performed the dialogue fifty times with the traders in Surakarta to search a viable solution in revitalizing the traditional market. ${ }^{51}$ Salahuddin's suggestion to empower the majority of the havenots is worth remarking, since it will gradually eliminate the discrepancy between the minority of the haves and the majority of the have-nots. The envy of this majority is considered potential to elicit tension (and consequently violence) to the minority. Economic factors are believed to be the main trigger of this intolerance, rather than some other factors as political and cultural factors.

This does not necessarily negate any political factors in triggering the violence; such as the existence of intolerant groups which seeks to get a certain political advantage from the occurrence of violence. Palguna rightly points out that in such a democratic society, like Indonesia, coercions to individual freedom no longer principally come from the

\footnotetext{
${ }^{49}$ Moch Nur Ichwan, "Towards a Puritanical Moderate Islam: The Majelis Ulama Indonesia and the Politics of Religious Orthodoxy", in Contemporary Developments in Indonesian Islam: Explaining the 'Conservative Turn, ed. by Martin Van Bruinessen (Singapore: Institute of Southeast Asian Studies, 2013), pp. 60-1.

${ }^{50}$ Wahid, Berguru pada Realitas, p. 107.

${ }^{51}$ Ibid., p. 108.
} 
state (and its apparatus) but rather from a certain intolerant segments within the society. ${ }^{52}$

\section{Salabuddin Wabid and Women's Rights}

Salahuddin pays a certain attention to women's rights. This can be observed for instance from a question posed by one Twitter user, namely, "An unregistered marriage (nikah sir), which is performed by many kiais in Indonesia, falls within the category of individual right. Why does the state intervene to this matter?" Replying to this question, Salahuddin asserts that, "it is the responsibility of the state to protect the women".

Salahuddin's concern with women's rights can be also detected from the following excerpt, in which he underlines the negative effects of polygyny and unregistered marriage to women:

The state is to respect the opinion of minority of Indonesian Muslims who allow such a marriage by providing a chance to register their marriage to the Office of Civil Registration, so that their marriage is considered legitimate in the eye of the state. If the state explicitly forbids such a marriage, it would mean that the couple violate the state law and accordingly are susceptible to sanction. The same condition would be applied if the Act forbids poligyny, the couple who perform this kind of marriage would be sanctioned. How it is if this polygny is not registered $($ sirr $)$ ? Can an unregistered marriage be considered as violation to the state law and accordingly is liable to sanction? Is an unregistered marriage considered as void an accordingly is not subject to any sanction. If [the latter] becomes the case, the second wife and her children would undergo discriminative action because there is probability that they would not obtain the same rights as the first wife and her descendants. The first wife and her descendants would be also aggrieved, but the husband could not be penalized. ${ }^{53}$

In the eyes of Salahuddin, the enactment which sets 30 percent quota for women in the parliament as of February 2003 is of the best achievement of women's movement. This quota allocation can be deemed as an affirmative action towards the women which had been marginalized. This affirmative action has rendered a new bargaining to the polemics on the validity of female president which was prevalent during the general election in 1999. At that time, many Muslim personages held the opinion that a female president is not allowed in Islamic law. The enactment of

${ }^{52}$ Palguna, "Minority Rights in Indonesia", p. 131.

${ }^{53}$ Wahid, Berguru pada Realitas, p. 245. 
quota for women in the parliament has forced many parties, including Muslim personages, in reconsidering the issue of female president more comprehensively. ${ }^{54}$

At this point, Salahuddin sees the interplays between the prescriptions of Islamic law and constitutional law. What is also worth stressing is the existence of varied standpoints within the Muslim scholars pertaining to the possibility of female ruler. The root of dispute is a differing interpretation regarding a prophetic saying that people who hand over their affairs to a woman will not succeed. Many muslim scholars interpret this hadith and are accordingly convinced that entrusting a woman as state ruler is illegitimate. Some other scholars perceive this hadith from another angle, namely from its historical context: at the moment a woman does not have any capacity of ruling a certain country she would not allowed to serve as state ruler, but if another moment (of history) shows that a certain woman possesses a leadership capacity, appointing her as state ruler would be not a problem.

These latter scholars base their arguments on the specific historical context in which this hadith was issued. It is reported that the Prophet issued this badith in response to one Persian Caesar who assigned his daughter as his successor. The Prophet heard information that this female successor did not have adequate leadership capacity. ${ }^{55} \mathrm{At}$ this point we may see that these latter scholars stick to the principle of Islamic jurisprudence: al-ibra bi-khusüs al-sabab la bi-'umüm al-laf乏 (the general rule usually observed is that one goes by the specific meaning suggested by the specificity of the case rather than simply the general sense of such words).

Salahuddin is aware that granting women's rights through political breakthrough is not supported by the cultural structure which is compatible with gender equality, and this needs a process, with the passage of time. He highlights another obstacle in implementing this quota allocation, namely whether this policy will be followed by the increasing capacity of women in public life. In the logic of managing modern public life, capacity is the only requirement which applies for both men and women. Marginalization of women which happens since

${ }^{54}$ Ibid., pp. $402-3$.

${ }^{55}$ Mohammad Monib and Islah Bahraw, Islam dan Hak Asasi Manusia dalam Pandangan Nurcholish Madjid (Jakarta: Gramedia Pustaka Utama, 2011), p. 257. 
long time ago automatically decreases the competency of women. ${ }^{56}$

\section{Salabuddin Wabid and Religious Minorities}

One Twitter account posed a question to Salahuddin whether Salahuddin would support if the minister of religion hails from the circle of the Shi'a. Salahuddin responded to this enquiry by stating that the minister of religion should not come from political party and should not create a problem (May 3, 2014). Salahuddin went to say that the appointment of minister of religion from the Shi'a would trigger a problem since there would be many protests from those not Shi'ite. The same case would happen if the minister of religion were appointed from the Ahmadiyya (May 4, 2014). It seems to me that this question was posed in respond the current rumour that a Shi'ite leader may be appointed as the minister of religion if Joko Widodo were elected as the president. In this regard, we may discern that Salahuddin is against the idea of appointing minister of religion from a minority Muslim group, since it is potential to trigger some problems which would hinder inner- and inter-religious harmony in the country. This appointment is susceptible of protests from many religious groups, most particularly the majority. Salahuddin's statement implies that the minister of religion should hail from the majority Muslim group, with a certain characteristics: (a) respecting the rights of minority and promoting harmony; (b) being not fond of creating problems; (c) being not affiliated with a certain political party. Salahuddin's hesitance to appoint the candidate of minister of religion who hails from a political party is seemingly due to his concern with the phenomenon of politicization of religion. Some politicians are suspected to make use of religion for political purpose, most particularly by employing anti-minority sentiments to attract votes from the conservative groups.

Elsewhere, Salahuddin some other criteria for electing somebody as the minister of religion, by saying: "Acceptability is one of the factors to assess who is the right person for such a political position as a minister of religion. The figure is to understand the position of religion in the context of nation-state. In addition, he/she is to comprehend the State Constitution. He/she is likewise to be able to communicate with many parties. ${ }^{57}$

${ }^{56}$ Salahuddin Wahid, Berguru pada Realitas: Refleksi Pemikiran Menuju Indonesia Bermartabat (Malang: UIN-Maliki Press, 2011), p. 402.

${ }^{57}$ Ib id., p. 315. 
Salahuddin's specific concern with human rights is also apparent from his conversation with Joko Widodo. Salahuddin's Twitter account listed some of his recommendations pertaining to the future of Indonesia. First, the necessity of law enforcement and fulfilment of human rights (which include economic, social and cultural rights). Second, bureaucratic reform. Third, the establishment of ministry of taxation. Fourth, economic sovereignty (May 3, 2014).

During Indonesian general election in 2014, minority issues have been used by many personages to attract supports from some religious mass-organizations. The support of the United Development Party's chairman towards anti-Shi'a movement in Indonesia can be deemed to be a strategy to attract sympathy from some Muslim massorganizations, most particularly the radicals. We also notice that there have been tendency to politicize the anti-Shi'a sentiment in Indonesia. On 21April 2014, for instance, the representatives of twelve Muslim mass-organizations gathered in Bandung, West Java, and formed the so-called "The National Alliance of Anti-Shi'a". One of the initiator of this alliance, Ahmad Cholil Ridwan, argued that the people should not give their vote to Joko Widodo because if Joko Widodo were elected as a president he would appoint Jalaluddin Rahmat (Indonesian Shi'ite leader) as the minister of religion. ${ }^{58}$

The moderate Muslims and secular nationalists show their distinct position towards minority and freedom of religion. They are also sensitive to the issues of minority rights and religious freedom. An instance of this is a criticism made by some scholars and activists pertaining to the manifesto of Great Indonesia Movement Party (Gerindra), of which one of its articles seems to hinder the religious freedom in the country, and consequently suppress the rights of minority religious groups. The article of this manifesto reads as follows, "The government/state is to regulate the freedom of citizens in performing their respective religions or beliefs. The states are also required to ensure the purity of the religions, which has been recognized by the state, from all forms of defamation and misuse". ${ }^{59}$

58 "Aliansi Nasional Anti Syiah Khawatirkan Jokowi Jadi Presiden", Satuislam. org (22 Apr 2014), http://www.satuislam.org/nasional/aliansi-nasional-anti-syiahkhawatirkan-jokowi-jadi-presiden/, accessed 29 Apr 2014.

${ }^{59}$ One of media reports pertaining to this is "Peneliti LIPI: Kaum Minoritas Terancam Jika Prabowo Presiden", Tribunnews.com (25 Apr 2014), http://www. tribunnews.com/pemilu-2014/2014/04/25/peneliti-lipi-kaum-minoritas-terancamjika-prabowo-presiden, accessed 4 May 2014. 
Ronald M. Hartwell, as cited by Ebeling, conceives politicization as "pervasive tendency for making all questions political questions, all issues political issues, all values political values, and all decisions political decisions...." Ebeling goes on to stress that "politicization thus takes the manifest form of increasing the power of the state, of increasing political power as against all other forms of power in society, of increasing the power of the politicians and the bureaucrats as against the power of individuals, private institutions, and voluntary associations...." ${ }^{60}$ Erdogan, construes politicization as the utilizing of an issue by politicians for the sake of taking full advantage of their votes. ${ }^{61} \mathrm{It}$ is worth remarking that the word "politics" itself can be understood in specific sense (namely: something to do with political party) and in generic and extensive sense (namely: the power of influencing policy-making). ${ }^{62}$

The present-day Indonesia witnesses the politicization of Shi'ism, most particularly prior to and during the general election and presidential election. Some political parties exploit anti-Shi'ite sentiments within the Sunni-majority Muslim country as Indonesia, to maximize their votes from the majority of the population. They accuse their rivals as taking side with Shi'ite ideas and personages, and subsequently discourage the people from giving votes to these rivals. This politicization of Shi'ism is considered strategic in attracting sympathy and votes from the majority of the population, since Shi'ism has been stigmatized by the Sunni-majority as deviant sect.

The party rivals, which assign some Shi'ite personages as legislature candidates, can be also considered as politicizing the Shi'ism. These parties bring forward such ideas as Islamic moderatism (wasatiyya), reconciliation of Islamic schools, pluralism and tolerance, to support and legitimize their acknowledgment of Shi'ism in the country. Such a strategy is not significant in winning more votes and sympathies, but will constitute an important contribution for the consolidation of democracy in the country.

${ }^{60}$ Werner Ebeling, Victor Yu. Podlipchuk, and Alexander A. Valuev, "Molecular Dynamics Simulation of The Activation of Soft Molecules Solved in Condensed Media", Physica A: Statistical Mechanics and its Applications, vol. 217, no. 1-2 (1995), p. v.

${ }^{61}$ Turan Erdogan, "Fiber Grating Spectra”, Journal of Lightwave Technology, vol. 15, no. 8 (1997), p. 22.

${ }^{62}$ Ibid., p. 9. 


\section{Salabuddin Wabid and Dialogue Initiative in Minimizing the Violence Against the Abmadiyya}

To eliminate the cases of violence against minorities, most particularly the Ahmadiyya, Salahuddin brings forward two apparent strategies: (a) anti-violence campaign; (b) dialogue. ${ }^{63}$ Salahuddin recommends the campaigns to prevent violence against suspected religious sect. This campaign is to be performed by the Majelis Ulama Indonesia, Islamic organizations, and state authorities, especially in conflict-prone areas like Manis Lor (Kuningan, West Java) and Pancor (Lombok, West Nusa Tenggara). ${ }^{64}$

It is worth mentioning that the presence of Ahmadiyya in Indonesian archipelago has been felt since 1920s. The Lahore branch of the Ahmadiyya in the country established the "Indonesian Ahmadiyya Movement" (Gerakan Ahmadiyya Indonesia, GAI), whilst the Qadiani branch organized themselves into the "Indonesian Ahmadiyya Congregation" (Jamaah Ahmadiyya Indonesia, JAI). These two factions have successfully attracted more than 300,000 followers across the country. The Ahmadiyya constitutes a religious minority in Indonesia, and accordingly it has to deal with the boundaries of religious freedom which it could exercise in Sunni-majority Indonesia. ${ }^{65}$

In line with this, Salahuddin felt the necessity of educating people regarding the difference implication of Islamic law and state law. Such awareness is considered significant in minimizing the violence against religious minorities. This can be observed from the subsequent quotation:

Another thing that should be explained to the public is the fact that Indonesia is not an Islamic state. What apply in our country are Indonesia's national laws. The provisions of Islamic law are only applied in Indonesia if they have been absorbed into our national law. It should be explained that if somebody violates a certain injunction of Islamic law but does not break the state law, [he/she cannot be penalized]. Thus, somebody else who penalizes this person is considered as someone who breaks the law. It is worth explaining, that those entitled and obliged to take action against violators of state law is law enforcers, not anyone. Muslim leaders should give such an explanation to their followers. ${ }^{66}$

${ }^{63}$ Wahid, Berguru pada Realitas, p. 300.

${ }^{64}$ Ibid.

${ }^{65}$ Melissa Crouch, Indonesia, Militant Islam and Abmadiyab: Origins and Implications, SSRN Scholarly Paper, no. ID 1551645 (New York: Social Science Research Network, 2010), pp. 4-5.

${ }^{66}$ Wahid, Berguru pada Realitas, pp. 306-07. 
At this point we may become aware of the projective facet of Salahuddin's agency. We may suppose that Salahuddin's strategy in addressing radicalism and intolerance within Muslim community, not within other faith communities, is not without grounds and is related to the future possible trajectories of his action. Firstly, Salahuddin is a Muslim scholar, and he felt that one of his social roles is to counsel and nurture the Muslim community; the efforts to advise the radical groups within other faith communities lie predominantly within the responsibilities of the scholars of these respective faith communities. Secondly, Salahuddin is yearning that the Muslim community, most notably in Indonesia, could set as an exemplary tolerant Muslim community so as to reduce the negative images of Islam as epistomized in western media.

Salahuddin suggests the performance of dialogue which involves all related parties: Ministry of Religious Affairs, Attorney General, Indonesian National Police, National Commission of Human Rights, the Constitutional Court, People's Representative Council, Majelis Ulama Indonesia, Ahmadiyya, Muhammadiyah, Nahdlatul Ulama, other Islamic organizations, leading universities, and experts. Salahuddin goes on to assert that the dialogue should be conducted with an open heart and mind, not to be a priori, there should be no intimidation. If such a dialogue cannot answer the problem of Ahmadiyya, it means that the nation fails to answer one of its fundamental problems. ${ }^{67}$

During the dialogue, it can be discussed whether the Ahmadiyya adherents have the right to live in Indonesia, by referring to Islamic law, National Constitution, and human rights principles. ${ }^{68}$ At this juncture, we may perceive that Salahuddin regards that Islamic law alone cannot serve as a basis of prohibiting the Ahmadiyya in the country, since Indonesia is not an Islamic state. Salahuddin goes on to explain about the dialogue:

Such a dialogue is apparently not able to solve all the problems in one time. All arguments should be stated frankly. Is it true that the Ahmadiyya possesses a scripture which is distinct from the Koran? Is it true that the creed of Ahmadiyya differs to that of [orthodox] Muslims? All necessary evidences should be brought in their original forms. If we cannot solve well this sensitive problem, what would be the Indonesian people?. ${ }^{69}$

\footnotetext{
${ }^{67}$ Ibid., p. 315.

${ }^{68}$ Ibid., p. 300.

${ }^{69}$ Ibid., p. 319.
} 
Salahuddin is conscious that the theological arguments should be also brought forward in the dialogue:

I heard there is something new in the arguments of Ahmadiyya. It says that the meaning of "the prophethood of Mirza Ghulam Ahmad" is in the sense that it is a form of revival of Prophet Isa (would this insult Christians?) and also as imam mahdi. Dawam Rahardjo and Abdul Muzawir (the chairman of Ahmadiyya Youth) said that the Tadhkira of Mirza Ghulam Ahmad is not a scripture but rather a record of Mirza Ghulam Ahmad's sayings. All these arguments should be discussed properly at that dialogue. $^{70}$

Salahuddin is aware of the limited reception of his idea to perform dialogue:

Many people would not agree with the suggestion of performing dialogue. The parties who commit violence certainly would not agree. The Majelis Ulama Indonesia probably would not consider that such a dialogue is important. They argue that Ahmadiyya acknowledge Mirza Ghulam Ahmad as a prophet, and this runs in counter to the Islamic faith, accordingly Ahmadiyya is false and misleading. That is it, no need for any dialogue. On the other hand, Ahmadiyya and their supporters who ground their viewpoint on the principles of human rights would say that the right to live in Indonesia is guaranteed by the State Constitution. No need to have any kind of dialogue. Full stop. If the elites of both parties have a certain a priori attitude, it would not surprise if the fanatical followers at the grass root would be also a priori. These people at the grass root only imitate what their elites do. If the elites of both parties are reluctant to participate in dialogue, and conversely attack each other in the media, would it be logical if we wish the changing of attitude at the grass root level?. ${ }^{71}$

It is interesting to examine whether Salahuddin's roles in eliminating radical tendency and violence within the Muslim community are in line with the established patterns within the Nahdlatul Ulama. At this point, I allude to Emirbayer's and Mische's three constitutive features of agency: iterational, projective and practical-evaluative. ${ }^{72}$ The iterational dimension

\footnotetext{
${ }^{70}$ Ibid., p. 323.

${ }^{71}$ Ibid.

${ }^{72}$ Mustafa Emirbayer and Ann Mische, "What Is Agency?", American Journal of Sociology, vol. 103, no. 4 (1998), p. 971.
} 
of Salahuddin's agency is observable in the condition in which Salahuddin reactivate parts of the Nahdlatul Ulama's patterns of thought and action pertaining to moderate religiosity, most particularly as embodied in the principle of "moderate and balance". Salahuddin's activism within the National Commission of Human Rights has also played a role in shaping his attitude towards violence in the name of religion.

The practical-evaluative element of Salahuddin's agency can be perceived from the condition in which Salahuddin makes practical and normative judgements among alternative possible trajectories of action, including the increasing plurality within the Nahdlatul Ulama leadership (ranging from "liberal" to "conservative-literal"); the involvement of the members of the Nahdlatul Ulama in some political parties with their respective ideologies; the existence of the members who stick to the international covenants of human rights and neglect the prescriptions of Islam; as well as the incoming of transnational Muslim actors which alter the religious field in contemporary Indonesia. When I look to Salahuddin's ideas pertaining to dialogue initiative to solve the problem of Ahmadiyya, I begin to realize that Salahuddin felt the necessity of synergizing the paradigms of human rights covenants with those of Islamic law to achieve a viable solution pertaining to Ahmadiyya. Such a convergence is for Salahuddin importance since Indonesia is neither secular nor theocratic state.

The projective aspect of Salahuddin's agency can be observed in the condition in which Salahuddin reconfigures possible future trajectories of action in conformity with his hopes, fears, and desires for the future. Salahuddin is aware of the increasing conservativism within the Muslim community as well as the increasing aspiration and activism to challenge the pluralism of the country, in particular, and to endanger the world peace, in general. Salahuddin's concerns with the sustainability of the multicultural Indonesia have driven him to undertake some necessary actions to promote moderate religiosity through various media including his writing, his position at the Pesantren Tebuireng and his networking with some human rights activists.

\section{Salabuddin Wabid and the Marriage of Religious Minorities}

Salahuddin employs the paradigm of "the Pancasila state which is based on belief in one God" in perceiving the regulation on marriage, in particular, and the legal matter, in general. This means that the People's Representative Council may not produce a positive law that runs contrary 
to the principles of Islamic law which are agreed by the majority of Muslims in Indonesia. This also means the people may not forbid the opinion minority Indonesian Muslims. ${ }^{73}$ This shows Salahuddin's respect to the opinion of minority Indonesian Muslims, and accordingly he is conscious and appreciative towards inner-Islamic plurality.

Regarding the issue of inter-faith marriage, Salahuddin says, "As a person, I would stick to the opinion of majority of Muslims that a muslim woman cannot marry to a non-muslim man. Nevertheless I would not agree if the state law explicitly permit or forbid such a marriage. This is the domain of Islamic law, and there is a dissent within the muslim community pertaining to that matter, and according the state is not to intervene with this". ${ }^{74}$

Salahuddin goes on to argue:

Just let the condition as it is now, in which the Act Number 1/1974 on marriage regulates that a marriage is valid if it is performed in accordance with the provisions of people's respective religions. According to the majority of Indonesian Muslims, the marriage between a Muslim woman and a non-Muslim man is not legitimate. It is clear that the state is not to intervene this by permitting such a marriage, which means that this would run contrary to the viewpoint of majority of Indonesian muslims. ${ }^{75}$

Salahuddin's specific concern with the opinion of minority of Indonesian Muslims is observable in the following excerpts: "The state is to respect the opinion of minority of Indonesian Muslims who allow such a marriage by providing a chance to register their marriage to the Office of Civil Registration, so that their marriage is considered legitimate in the eye of the state. If the state explicitly forbids such a marriage, it would mean that the couple violate the state law and accordingly are susceptible to sanction". ${ }^{76}$

At this juncture, we may see that Salahuddin's viewpoint pertaining to marriage stands between two extreme pools. On the one hand, we encounter the standpoints of such a scholar as Adian Husaini ${ }^{17}$ who wishes to incorporate all provisions of Islamic law in positive law. On the other hand, we come across such a scholar as Abdurrahman Wahid

${ }^{73}$ Wahid, Berguru pada Realitas, p. 244.

${ }^{74}$ Ibid.

${ }^{75}$ Ibid., pp. $244-45$.

${ }^{76}$ Ibid., p. 245.

${ }^{77}$ Adian Husaini, "Pernikahan Lintas Agama", Republika (15 Apr 2005). 
to formulate a secular marriage Act.

In the eyes of Adian Husaini, all authoritative Muslim scholars are agreed that the marriage between a Muslim woman and a non-Muslim man is forbidden according to the prescription of Islamic law. Husaini denied the existence of a small number of Muslim scholars who allow such a marriage. He as if doubts the credibility of the small number of Muslim scholars as can be observed from this quotation: "Of course, "Muslim scholars" (ulama) who are mentioned here are the real Muslim scholars, who have the capacity to perform ijtihad (independent reasoning) in deciding a legal status of a certain issue based on valid methodology". ${ }^{78}$

In addition, Husaini criticizes those who consent to the marriage between a Muslim woman and a non-Muslim man by basing their arguments on gender equality: "If the logic of secular human rights, religious pluralism and gender equality are employed to justify the validity of the marriage of a Muslim woman and a non-Muslim man, then this logic will drag them to the vicious circle of liberalism, as occurs in the case of homosexuals in Western countries nowadays ${ }^{79}$

Salahuddin considers such figures as Abdurahman Wahid, Ulil Abshar Abdalla and Dawam Rahardjo to be the personages which tend to aspire for a secular state. It is worth mentioning that Salahuddin understands secular state, most particularly in the context of Indonesia, as a state that does not give any chance for the inclusion of "particularistic" provisions of Islamic law, but does not negate its "universal" provisions. ${ }^{80}$

Salahuddin disagrees with Abdurrahman Wahid pertaining to marriage Act and its excess on Confucianism (one of the minority religions in Indonesia). ${ }^{81}$ It is worth mentioning that in 1998, Abdurrahman once became a witness in the regency court of Surabaya, East Java, pertaining the session on the adherents of Confucianism who are not allowed to registry their marriage in the Office of Civil Service, since Confucianism at that time was unrecognized religion. These adherents were forced to profess themselves as Buddhists in order their marriage to be registered. ${ }^{82}$

Salahuddin points out that there were efforts from the secular-

${ }^{78}$ Ibid.

${ }^{79}$ Ibid.

${ }^{80}$ Wahid, Berguru pada Realitas, p. 246.

${ }^{81}$ Salahuddin Wahid, "Negara Demokrasi Tidak Mesti Negara Sekuler", PCINU MESIR (2014), http://pcinu-mesir.tripod.com/ilmiah/pusaka/ispustaka/buku09/005. htm, accessed 28 Mar 2014.

${ }^{82}$ Wahid, Berguru pada Realitas, p. 414. 
nationalist group who strived to establish a secular state by proposing draft bills on marriage which do not conform to Islamic law. The fraction of "United Development" within the People's Representative Council was against this idea, and was eventually successful in including the elements of Islamic law in this Act. And this, according to Salahuddin, signified the beginning of "Pancasila state" which is based on "belief in one God". 83

Due to the protest of "United Development" fraction and many Muslim mass-organizations, the People's Representative Council eventually formulated the Article 1 of the Act which "determines that the marriage is legitimate if it is done in accordance with the laws of one's respective religion". Salahuddin points out that this Act is the first Act that provides a space for the inclusion of the particular provisions of Islamic law. ${ }^{84}$

Salahuddin also realizes the excess of this Act on the adherents of Confucianism, whose religious rights and marital status were violated by this Act. In addition, he appreciates Abdurrahman who defended the adherents of Confucianism. Nevertheless, he is of the opinion that with this excess, it does not necessarily mean that we should abolish this marriage Act, which has been in conformity with Islamic law. ${ }^{85}$ According to Salahuddin, this marriage Act protects the Muslim community who wish to marry according to the injunctions of Islamic law and, at the same time, in conformity to marriage Act laid down by People's Representative Council. ${ }^{86}$

In the eyes of Salahuddin, the difference between the "Pancasila state" which is based on "belief in one God" and the state which is based on "Jakarta charter", lies on the fact that the former necessitates a limited version of legalization of Islamic law. ${ }^{87} \mathrm{It}$ is worth noticing that the "Jakarta charter" was issued on June 22, 2014 and pointed five pillars of the coming Indonesia, of which the first pillar read as "the divinity, with the obligation of performing the injunctions of Islamic law for the adherents of this religion".

\footnotetext{
${ }^{83}$ Wahid, "Negara Demokrasi”.

${ }^{84}$ Salahuddin Wahid, "Menimbang Partai Islam”, Kompas.com (15 Apr 2014), http://indonesiasatu.kompas.com/read/2014/04/15/1105340/menimbang.partai. islam, accessed 29 Apr 2014.

${ }^{85}$ Wahid, "Negara Demokrasi”.

${ }^{86}$ Din Wahid, Anatomi Gerakan Salafi di Indonesia (PKM II Kampus I STAIN Salatiga, 28 May 2014).

${ }^{87}$ Ibid. 


\section{E. Concluding Remarks}

Salahuddin Wahid assumes varied role ranging from engineer, politician, human rights activist and Muslim scholar. He possesses some credentials which allow him to become an authority in Islamic matters. Salahuddin's recognition as muslim scholar is in some ways observable from his responses to religious questions posed by the people, either directly or through social media. Any general observation of Salahuddin's Twitter account, will allows us to realize that he also represent an authority in "cyber-Islam". He felt the growing importance of social media, as well as the necessity to promote inclusive religiosity and the respect of minority rights through social media; accordingly he actively promotes his ideas through social media most particularly Twitter.

Salahuddin has done his best to promote minority rights. His activism can be felt most notably in the following issues: ethnic minorities, women's rights, religious minorities, diminishing the violence against the Ahmadiyya, and the marriage of religious minorities.

This paper strives to show that minority rights can be effortlessly promoted within the framework of "traditionalist" ideas when the actors possess the credibility among the majority of citizens. Accordingly, traditionalist Muslim scholar such as Salahuddin may play a strong role in advocating the virtues of minority rights in the Indonesian society in general, and among Indonesian Sunni-Muslim majority, in particular. 


\section{BIBLIOGRAPHY}

"Aliansi Nasional Anti Syiah Khawatirkan Jokowi jadi Presiden", Satuislam. org, 22 Apr 2014, http://www.satuislam.org/nasional/aliansinasional-anti-syiah-khawatirkan-jokowi-jadi-presiden/, accessed 29 Apr 2014.

Ali, Muhamad, "Moderate Islam Movement in Contemporary Indonesia", in Islamic Thought and Movements in Contemporary Indonesia, ed. by Rizal Sukma and Clara Joewono, Jakarta: Centre for Strategic and International Studies, 2007, pp. 195-236.

Anderson, Richard C., "How to Construct Achievement Tests to Assess Comprehension", Review of Educational Research, vol. 42, no. 2, 1972, pp. 145-70 [http://dx.doi.org/10.3102/00346543042002145].

Atmasari, Rina, "Soal Lurah Susan, Ini Kata Gus Sholah", Tempo.co, 13 Jul 2013, http://www.tempo.co/read/news/2013/08/23/083506850/ Soal-Lurah-Susan-Ini-Kata-Gus-Sholah, accessed 9 Sep 2013.

Bendix, Reinhard, "Reflections on Charismatic Leadership", Asian Survey, vol. 7, no. 6, 1967, pp. 341-52 [http://dx.doi.org/10.1525/ as.1967.7.6.01p02742].

Crouch, Melissa, Indonesia, Militant Islam and Abmadiyah: Origins and Implications, SSRN Scholarly Paper, no. ID 1551645, New York: Social Science Research Network, 2010, http://papers.ssrn.com/ abstract $=1551645$, accessed 6 Nov 2014.

Dirdjosanjoto, Pradjarta, Memelihara Umat: Kiai Pesantren, Kiai Langgar di Jawa, Yogyakarta: LKiS, 1999.

"Doctor HC Pertama di UIN Maliki", The Center of Excellence and Islamic Civilization, 9 Oct 2011, http:/ / uinsite.uin-malang.ac.id/ blog/2011/12/doctor-hc-pertama-di-uin-maliki, accessed 17 Sep 2013.

Duncan, Christopher R., "From Development to Empowerment: Changing Indonesian Government Policies toward Indigenous Minorities", in Civilizing the Margins: Southeast Asian Government Policies for the Development of Minorities, ed. by Christopher R. Duncan, Ithaca: Cornell University Press, 2004, pp. 86-115.

Ebeling, Werner, Victor Yu. Podlipchuk, and Alexander A. Valuev, "Molecular Dynamics Simulation of The Activation of Soft Molecules Solved in Condensed Media", Physica A: Statistical Mechanics 
and its Applications, vol. 217, no. 1-2, 1995, pp. 22-37 [http://dx.doi. org/10.1016/0378-4371(95)00049-D].

Emirbayer, Mustafa and Ann Mische, "What Is Agency?", American Journal of Sociology, vol. 103, no. 4, 1998, pp. 962-1023 [http://dx.doi. org/10.1086/231294].

Erdogan, Turan, "Fiber Grating Spectra”, Journal of Lightwave Technology, vol. 15, no. 8, 1997, pp. 1277-94 [http://dx.doi.org/10.1109/50.618322].

Franke, Marburg and Katrin Gotterbarm, "Kritik durch Anpassung? Aluk to dolo und Christentum im Pancasila-Staat Indonesien", in Religionsinterne Kritik und religiöser Pluralismus im gegenwärtigen Südostasien, ed. by Manfred Hutter, Frankfurt: Peter Lang, 2008, pp. 215-30.

Friedman, Renee F. and Douglas J. Brewer, Fish and Fishing in Ancient Egypt, Cairo: American University in Cairo Press, 1990.

Geoffrey, Parrinder, "Peace", in The Encyclopedia of Religion, ed. by Mircea Eliade and Charles J. Adams, New York: Macmillan, 1987.

Hidayat, Arief Rizqi, "Salahuddin Wahid Sesalkan Sikap Ulama Madura", Tempo.co, 24 Jul 2013, http://www.tempo.co/read/ news/2013/07/24/078499266/Salahuddin-Wahid-Sesalkan-SikapUlama-Madura, accessed 17 Sep 2013.

Horikoshi, Hiroko, Kyai dan Perubahan Sosial: Kyai and Social Change, trans. by Umar Basalim and Andi Muarly Sunrawa, Jakarta: Perhimpunan Pengembangan Pesantren dan Masyarakat, 1987.

Humphreys, Lee M., Balachander Krishnamurthy, and Phillipa Gill, "How Much Is Too Much? Privacy Issues on Twitter", Paper presented at the annual meeting of the International Communication Association, Suntec City, Singapore, 21 Jun 2010, http:/ / www2.research.att.com/ bala/ papers/ica10.pdf, accessed 28 May 2014.

Humphreys, R. Stephen, Islamic History: A Framework for Inquiry, New York: Princeton University Press, 1991.

Husaini, Adian, "Pernikahan Lintas Agama”, Republika, 15 Apr 2005.

Ichwan, Moch Nur, "Towards a Puritanical Moderate Islam: The Majelis Ulama Indonesia and the Politics of Religious Orthodoxy", in Contemporary Developments in Indonesian Islam: Explaining the "Conservative Turn, ed. by Martin van Bruinessen, Singapore: Institute of Southeast Asian Studies, 2013, pp. 60-104.

Kymlicka, Will, Politics in the Vernacular: Nationalism, Multiculturalism, and 
Salahuddin Wahid and the Defence of Minority Rights

Citizenship, Oxford: Oxford University Press, 2001.

Lyons, G., "From Advanced Towards Effective Traveller Information Systems", in Travel Behaviour Research: The Leading Edge, ed. by David A. Hensher, Pergamon Press, 2001, pp. 813-26, http:/ / eprints.uwe. ac.uk/8550/1/8550.pdf, accessed 1 Jun 2014.

"Minorities Under International Law", United Nations Human Rights, 2010, http://www.ohchr.org/EN/Issues/Minorities/Pages / internationallaw.aspx, accessed 21 Sep 2013.

Monib, Mohammad and Islah Bahraw, Islam dan Hak Asasi Manusia dalam Pandangan Nurcholish Madjid, Jakarta: Gramedia Pustaka Utama, 2011.

Mulder, Niels, Mysticism and Everyday Life in Contemporary Java: Cultural Persistence and Change, Singapore: NUS Press, 1978.

Palguna, I. Dewa Gede, "Minority Rights in Indonesia: In Search of Suitable Legal Remedy for Constitutional Complaint", in State, Law and Religion in Pluralistic Societies Austrian and Indonesian Perspectives: Austrian-Indonesian Dialogue Symposium, ed. by Astrid Hafner, Sabine Kroissenbrunner, and Richard Potz, Vienna: Vandenhoeck \& Ruprecht, 2010, pp. 129-36.

"Peneliti LIPI: Kaum Minoritas Terancam Jika Prabowo Presiden", Tribunnews.com, 25 Apr 2014, http://www.tribunnews.com/ pemilu-2014/2014/04/25/peneliti-lipi-kaum-minoritas-terancamjika-prabowo-presiden, accessed 4 May 2014.

Rehman, Javaid, The Weaknesses in the International Protection of Minority Rights, Boston: Kluwer Law International, 2000.

Sardelić, Julija, “Constructing 'New' Minorities: An Evaluation of Approaches to Minority Protection in Post-Socialist Slovenia from the Perspective of Liberal Multiculturalism", Journal for Ethnic Studies, no. 67, 2012, pp. 100-23.

Syatiri, Ana Shofiana, "Kompas Anugerahi Lima Cendekiawan Berdedikasi 2013", Kompas.com, 27 Jun 2013, http:/ / sains.kompas. $\mathrm{com} / \mathrm{read} / 2013 / 06 / 27 / 1144192 /$ Kompas. Anugerahi.Lima, accessed 3 Sep 2013.

"Tanggapan Gus Sholah Terhadap Sosok Jokowi", Youtobe.com, 4 May 2014, https://www.youtube.com/watch?v=ugSXgLCx_ ys\&feature=youtube_gdata_player, accessed 17 Sep 2014.

Turner, Ralph H., "Role Theory", in Handbook of Sociological Theory, ed. 
by Jonathan H. Turner, New York: University of California, 2006.

Wahid, Din, Anatomi Gerakan Salafi di Indonesia, PKM II Kampus I STAIN Salatiga, 28 May 2014.

Wahid, Salahuddin, "Menimbang Partai Islam”, Kompas.com, 15 Apr 2014, http://indonesiasatu.kompas.com/read/2014/04/15/1105340/ menimbang.partai.islam, accessed 29 Apr 2014.

----, "Realitas 'NU' tidak Sesederhana yang Kita Bayangkan", in NU Politik: Analisis Wacana Media, ed. by Fathurin Zen, Yogyakarta: LKiS, 2003.

----, "Belajar dari Pemimpin Masa Lalu”, SuperKoran.info, 12 Mar 2007, http://superkoran.info/?p=1465, accessed 3 Dec 2007.

----, Berguru pada Realitas, Refleksi Pemikiran Menuju Indonesia Bermartabat, Malang: UIN-Maliki Press, 2011.

----, Transformasi Pesantren Tebuireng: Menjaga Tradisi di Tengah Tantangan, Malang: UIN Maliki Press, 2011.

----, “Saya sholat setelah Adzan@Randy_Hendra: @Gus_Sholah Sholat sunnat fajar itu sebelum adzan subuh atau antara adzan-Iqmah dan beda dengan sunnat Qobliyah?", Twitter.com, 00 - 29 Okt 2014, https://twitter.com/Gus_Sholah/statuses/527354232001671168, accessed 6 Nov 2014.

----, "Menurut saya tidak boleh.@sspamungkas: @Gus_Sholah@ pramono_ar@kurdiabujundi@bobihendra hukum tato Gus? menurut syariat Islam.”, Twitter.com, 28 - 29 Okt 2014, https:// twitter.com/Gus_Sholah/statuses/527300973262163968, accessed 14 Dec 2014.

----, “Jangan merokok di tempat umum. @bobihendra: Kiay @Gus_ Sholah , Bagaimana pendapat Kyai mengenai Mentri yang merokok dan bertato?", Twitter.com, 32 - 29 Okt 2014, https://twitter.com/ Gus_Sholah/statuses/527256640127389696, accessed 4 Nov 2014.

----, "Kalo sehat, berpahala. @ode_ahmad: menurut pandangan ISLAM \#DonorDarah itu Halal pa Haram pak@Gus_Sholah?”, Twitter.com, 26 - 30 Okt 2014, https://twitter.com/Gus_Sholah/ statuses/527768395953864704, accessed 22 Dec 2014.

----, "Fatwa itu tidak mengikat. @navikindi: Bukankah MUI sudah menfatwakan kharam Gus?@Gus_Sholah@bobihendra", Twitter.com, 59 - 29 Okt 2014, https://twitter.com/Gus_Sholah/ 
Salahuddin Wahid and the Defence of Minority Rights statuses/527263324442877952, accessed 2 Aug 2014.

----, "Berlaku hanya bagi yang percaya. @Condare: Apa fatwa tentang halal haram itu tidak berlaku atas semua orang? Aneh@navikindi @bobihendra", Twitter.com, 06 - 29 Okt 2014, https:/ / twitter.com/ Gus_Sholah/statuses/527295365783891969, accessed 2 Jun 2014.

----, “Tidak berlaku di RI.@aim_revolt:@fimadani Rajam dan Qishash gak ada di UU tapi ada di Qur'an. Gak berlaku berarti? Hebat. UU ngalahin Al-Qur'an", Twitter.com, 30 - 15 Okt 2014, https://twitter. com/Gus_Sholah/statuses/522227956358205440, accessed 2 Dec 2014.

----, "Hukum Agama berlaku bila Ada di dlm UU. @ you_bram: Pripun niki? -@fimadani: Ketua GP Ansor: Di Atas Hukum Agama Ada Konstitusi Negara", Twitter.com, 27 - 15 Okt 2014, https://twitter. com/Gus_Sholah/statuses/522212087397769216, accessed 2 Dec 2014.

----, “Hukum RI, Tidak mengenal itu. @lutfisarif: Assalamu’alaikum @ Gus_Sholah, bagaimana menurut njenengan hukum Al Khilafah atau Al Imamah Al 'Ushma?', Twitter.com, 13 - 30 Okt 2014, https:/ / twitter.com/Gus_Sholah/statuses/527750022335442944, accessed 2 Dec 2014.

----, “Negara Demokrasi Tidak Mesti Negara Sekuler", PCINU MESIR, 2014, http://pcinu-mesir.tripod.com/ilmiah/pusaka/ispustaka/ buku09/005.htm, accessed 28 Mar 2014.

----, "Menurut Saya tidak perlu.@pepesiwak:Yai@Gus_Sholah beberapa umat Islam di Indonesia menginginkan berdirinya Khilafah, masihkah perlu yai?'”, Twitter.com, 9 Nov 2014, https:// twitter.com/ Gus_Sholah/statuses/528369309114830850, accessed 9 Jun 2014. 